\title{
Publication trends in research on particulate matter and health impact over a 10-year period: 2009-2018
}

\author{
Jae-Eun Lee ${ }^{1}$, Hyun Joung Lim ${ }^{1}$ (D), and Young-Youl Kim ${ }^{1, *(\mathbb{D})}$ \\ ${ }^{1}$ Division of Allergy and Respiratory Disease Research, Department of Chronic Disease Convergence Research, National \\ Institute of Health, Korea Disease Control and Prevention Agency, South Korea \\ *Correspondence: youngyk@nih.go.kr
}

Received: November 5, 2020 Accepted: January 6, 2021

\begin{abstract}
Exposure to ambient particulate matter is a major health risk factor for numerous diseases, including those of the cardiovascular and respiratory varieties. The aim of this study was to estimate the latest global research activities regarding particulate matter and health impact. We performed a bibliometric analysis of this field's scientific publication trends over a decade (2009-2018). Publications were retrieved from the Scopus and Web of Science databases using the search terms "particulate matter," "fine particulate matter," "health impact," and their synonyms. The literature on health impact in the research fields of particulate matter (PM10) and fine particulate matter (PM2.5) trended to significantly increase over the decade in consideration. It appears to have been led by researchers of the United States and China. Worldwide research on particulate matter and health effects has focused primarily on respiratory and cardiovascular diseases. The precursors to and components of particulate matter (such as nitrogen dioxide, polycyclic aromatic hydrocarbon, sulfur dioxide, and black carbon) were also popular research topics in this field. Research on children, older adults, and pregnant women, who are most vulnerable to the health effects of air pollution, has increased dramatically over the past 10 years. Our findings provide the information necessary to predict unmet research topics and future research needs.
\end{abstract}

Keywords: air pollution, particulate matter, $\mathrm{PM}_{10}, \mathrm{PM}_{2.5}$, public health, publication trends

\section{Introduction}

Particulate matter in which $50 \%$ of the particles have an aerodynamic diameter lower than $10 \mu \mathrm{m}-\mathrm{PM}_{10}-$ is a major outdoor air pollutant [1]. Its detrimental effects include causing or worsening various diseases, including those of the cardiovascular and respiratory varieties [2]. Fine particulate matter with particulate size less than $2.5 \mu \mathrm{m}\left(\mathrm{PM}_{2.5}\right)$ is more harmful to health than PM10 [3]. As per the Global Burden of Diseases Study 2015, long-term exposure to ambient PM2.5 was the fifth leading worldwide cause of mortality, responsible for 4.2 million deaths (95\% uncertainty interval [UI] 3.7-4.8 million) [4].

Children, older adults, and pregnant women are especially vulnerable to the health effects of air pollution [5-7]. $\mathrm{PM}_{10}[8,9]$ and $\mathrm{PM}_{2.5}[8,10,11]$ have been shown to be associated with the development and worsening of asthma in about $10 \%$ of children worldwide. In the context of older adults, studies have reported a relationship between PM2.5 exposure and increased premature mortality rates [12,13]. Further, PM2.5 exposure during pregnancy is said to be associated with low birth weight and preterm birth [14], as well as the development of asthma at six years of age in boys [15].

Bibliometric analysis is a statistical method for analyzing research trends in a given domain, useful for comparing the contributions of countries, institutions, and journals [16]. While bibliometric studies on PM2.5 [17] and air pollution and human health [18] have been reported, particulate matter and its health impact has not yet been the subject of such analysis. Therefore, this study aims to analyze research trends and keywords regarding the particulate matter and associated health impacts over a 10-year period (2009-2018).

\section{Methods}

\section{Data sources and search strategy}

The literature searches in Scopus and Web of Science (WoS) were performed on August 27 and September 4, 2019, respectively. The WoS database included the Science Citation Index Expanded and Emerging Sources Citation Index. 
The search terms "particulate matter," "fine particulate matter," "health impact," and their synonyms were sought in the titles, abstracts, or keywords of studies available in the abovementioned databases. This study focuses only on journal articles; therefore, other document types (conference papers, reviews, notes, book chapters, conference reviews, errata, letters, short surveys, editorials, data papers, business articles, abstract reports, books, proceeding papers, meeting abstracts, editorial material, early access papers, corrections, news items, reprints, and retracted publications) were excluded.

The search process was as follows: publications on $\mathrm{PM}_{10}$ and $\mathrm{PM}_{2.5}$ published from 2009 to 2018 were first retrieved from Scopus and WoS. Then, health impact-associated publications were extracted from the retrieved PM10 and PM2.5-related publications. Subsequently, publications related to children, older adults, and pregnant women were retrieved from within the research field on PM2.5 and health impacts on December 8, 2020. Data regarding retrieved articles, including subject area (research area), source title (journal), country or territory (location), and affiliation (organization) were downloaded from the databases. The data on research area, journal, and organization of the publications downloaded from WoS were analyzed using InCites, an online bibliometric analysis tool (http://incites.clarivate.com).

The key phrase analysis for particulate matter and health impact-related publications retrieved from Scopus was performed using SciVal, another online bibliometric analysis tool (https://www.scival.com) on December 8-9, 2020. It was possible to analyze the literature from only 2010 to 2018 using SciVal. Therefore, the research direction of the last 10 years was estimated using this data. Search terms and their synonyms were excluded in the top 15 keywords.

\section{Statistical analysis}

Linear regression analysis to assess publication trends in the time period of interest was conducted using SPSS version 18.0 (IBM Inc, Chicago, IL, USA). Statistical significance was set at $\mathrm{p}<0.05$.

\section{Publication trends over 10 years}

Using Scopus, we identified a total of 48,267 PM10-related articles published from 2009 to 2018, of which 10,520 (21.8\% of the total PM10-related articles) concerned health impact (Figure 1). A total of 33,048 PM10-related publications were retrieved from WoS, of which 9,738 (29.5\%) were health impact-related. The overall number of health impact-oriented studies retrieved from Scopus (linear regression, correlation coefficient $(r)=0.983 ; p<0.001)$ and WoS $(r=0.965 ; p<0.001)$ increased at an annual average of $12.5 \%$ and $14.6 \%$, respectively.

Of the 20,462 PM2.5-related articles published between 2009 and 2018 retrieved from Scopus, 4,708 (23.0\% of the total PM2.5-related articles) were health impact-related. In WoS, of the 21,526 PM2.5-related publications identified, 5,711 $(26.5 \%)$ were health impact-related. The overall numbers of health impact-oriented studies retrieved from Scopus $(r=0.955$; $\mathrm{p}<0.001)$ and WoS $(\mathrm{r}=0.957 ; \mathrm{p}<0.001)$ demonstrated an increasing annual trend over 10 years, with average rates of $16.7 \%$ and $19.0 \%$, respectively. Among the number of publications on particulate matter (both $\mathrm{PM}_{10}$ and $\mathrm{PM}_{2.5}$ ), the proportion of publications on health impact trended to increase every year.

\section{Country, organization-stratified, and journal analyses}

Furthermore, we analyzed the data on countries, institutions, and journals that have directed research on the health effects of particulate matter, focusing on the period during 2014-2018 to observe the recent trends. Researchers from more than 100 countries or territories (Scopus $\left.=132 ; \mathrm{WoS}^{2} 109\right)$ published articles on PM10 and health impact between 2014 and 2018 (Figure 2). By country, the maximum volume was associated with the United States (Scopus $=2,362,35.0 \%$ of all publications on PM10 and health impact; $\mathrm{WoS}=2,409,37.1 \%$ ) and China (Scopus = 1,728, 25.6\%; WoS = 1,747, 26.9\%). Health impact-related publications from the United States and China alone accounted for more than 30\% (Scopus = 32.1\%; WOS = $38.7 \%$ ) and $18 \%$ (Scopus $=18.7 \%$; WoS $=27.9 \%$ ) of all PM10-related articles, respectively.

Approximately 100 countries or territories (Scopus = 103; WoS =94) contributed to research related to $\mathrm{PM}_{2.5}$ and its health impact between 2014 and 2018. By country, the maximum volume was associated with the United States (Scopus $=1,281,38.2 \%$ of all publications on $\mathrm{PM}_{2.5}$ and health impact; $\mathrm{WoS}=1,654,40.1 \%$ ) and China (Scopus = 1,082, 32.3\%; WoS = $1,311,31.8 \%)$. Health impact-related publications from the United States and China alone represented about $40 \%$ (Scopus $=$ $39.2 \%$; $\mathrm{WoS}=41.3 \%$ ) and over $19 \%$ (Scopus $=19.1 \%$; $\mathrm{WoS}=25.1 \%$ ) of all $\mathrm{PM}_{2.5}$-related articles, respectively.

We also investigated the 10 organizations that published the most articles on PM10 and health impact between 2014 and 2018 (Table 1a). In Scopus, the Chinese Academy of Sciences had the highest number of articles (278, 4.1\% of all publications on PM10 and health impact), followed by the Harvard School of Public Health (235, 3.5\%) and Peking University (194, 2.9\%). In WoS, Harvard University had the highest number of articles (389, 6.0\%), followed by the University of California system (303, 4.7\%) and Chinese Academy of Sciences (297, 4.6\%). 


\section{Scopus}

A

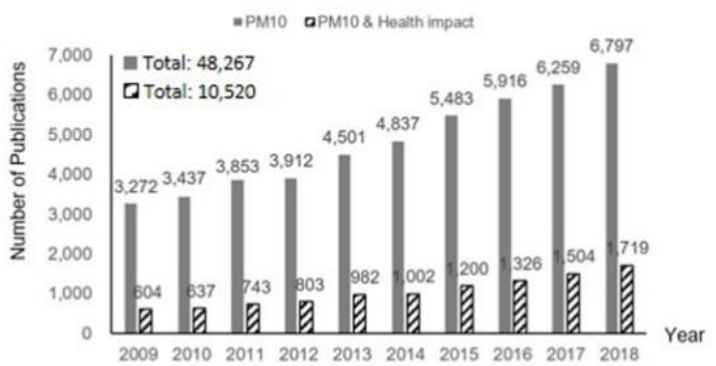

C

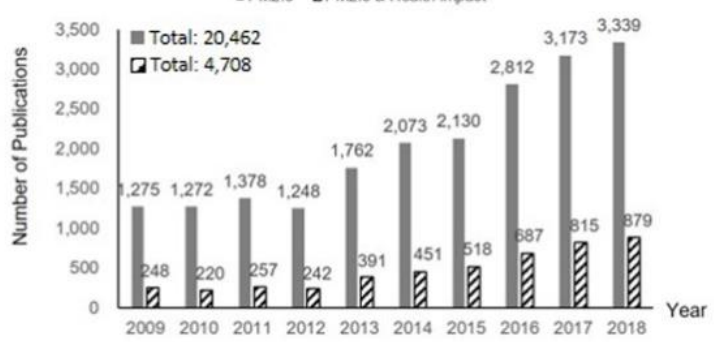

Web of Science

B

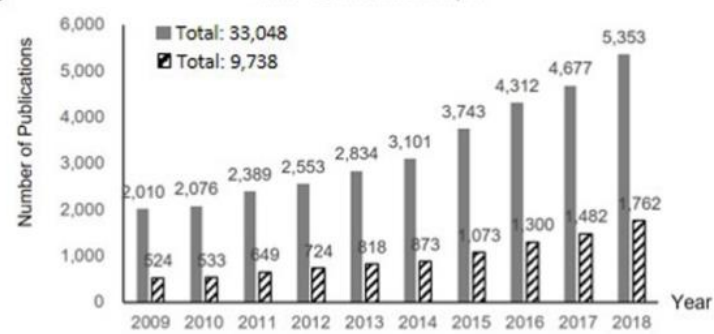

D

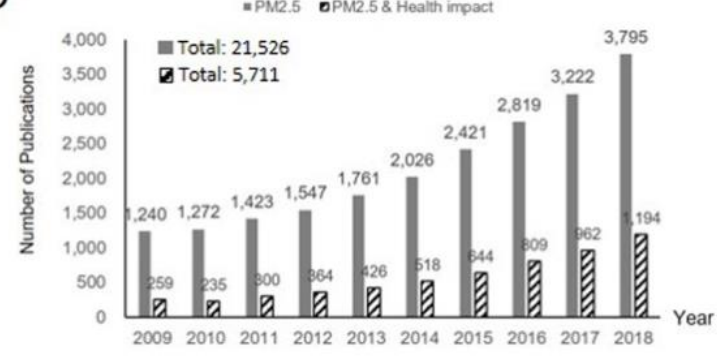

Figure 1. Publication trends of research on particulate matter and health impact. (A, C): Scopus data; (B, D): Web of Science data.

Scopus

A

هPM10 \& Health impact $=$ PM10

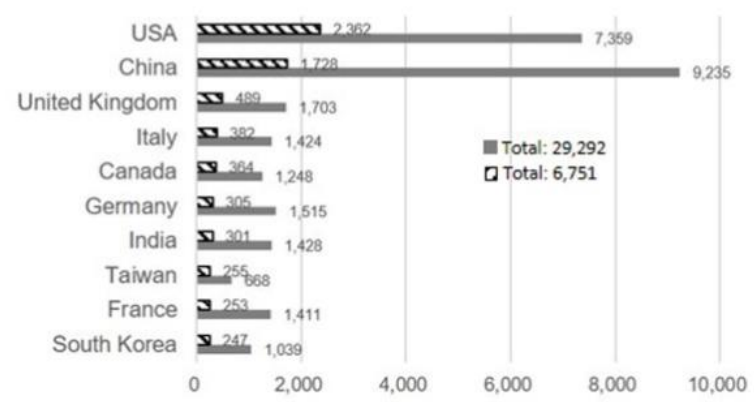

C

DPM2.5 \& Health impact $=$ PM2.5

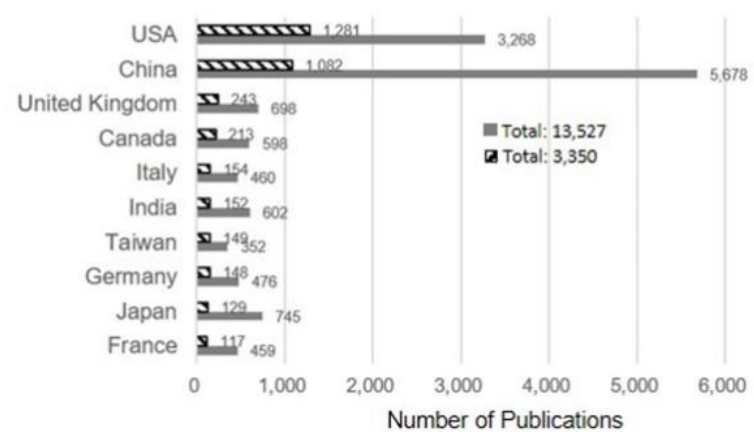

B

d PM10 \& Health impact $=$ PM10

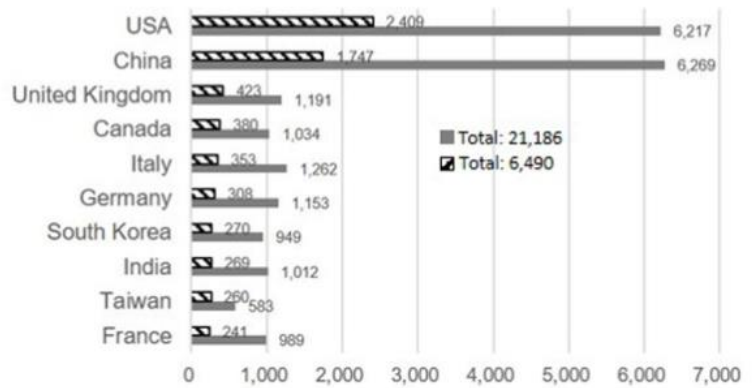

D

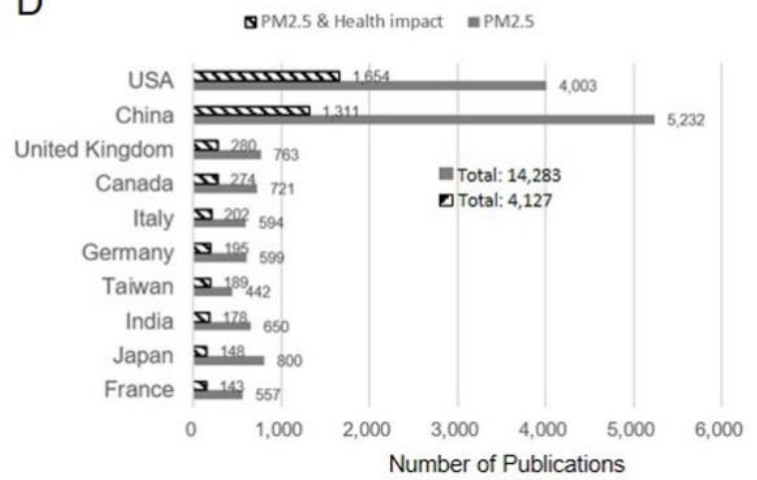

Figure 2. Top 10 countries regarding publication contribution. (A, C): Scopus data; (B, D): Web of Science data. 
1

2 Table 1a. Top 10 organizations and journals regarding research on PM10 and health impact (2014-2018).

3

\begin{tabular}{|c|c|c|c|c|c|c|c|}
\hline \multicolumn{4}{|c|}{ Scopus database } & \multicolumn{4}{|c|}{ Web of Science database } \\
\hline Organization & & Journal & & Organization & & Journal & \\
\hline \multicolumn{4}{|c|}{ Total number of publications : 6,751} & \multicolumn{4}{|c|}{ Total number of publications : 6,490} \\
\hline $\begin{array}{c}\text { Chinese Academy } \\
\text { of Sciences }\end{array}$ & 278 & $\begin{array}{l}\text { Science of the } \\
\text { Total } \\
\text { Environment }\end{array}$ & 376 & Harvard University & 389 & $\begin{array}{l}\text { Science of the Total } \\
\text { Environment }\end{array}$ & 341 \\
\hline $\begin{array}{l}\text { Harvard School of } \\
\text { Public Health }\end{array}$ & 235 & $\begin{array}{l}\text { Atmospheric } \\
\text { Environment }\end{array}$ & 281 & $\begin{array}{c}\text { University of } \\
\text { California system }\end{array}$ & 303 & $\begin{array}{l}\text { Atmospheric } \\
\text { Environment }\end{array}$ & 284 \\
\hline Peking University & 194 & $\begin{array}{l}\text { Environmental } \\
\text { Pollution }\end{array}$ & 249 & $\begin{array}{c}\text { Chinese Academy of } \\
\text { Sciences }\end{array}$ & 297 & $\begin{array}{l}\text { International Journal of } \\
\text { Environmental Research } \\
\text { and Public Health }\end{array}$ & 249 \\
\hline $\begin{array}{c}\text { Ministry of } \\
\text { Education China }\end{array}$ & 173 & $\begin{array}{c}\text { Environmental } \\
\text { Research }\end{array}$ & 249 & $\begin{array}{l}\text { Harvard T.H. Chan } \\
\text { School of Public } \\
\text { Health }\end{array}$ & 294 & Environmental Pollution & 245 \\
\hline $\begin{array}{l}\text { United States } \\
\text { Environmental }\end{array}$ & 153 & $\begin{array}{l}\text { International } \\
\text { Journal of }\end{array}$ & 244 & Peking University & 215 & Environmental Research & 235 \\
\hline Protection Agency & & $\begin{array}{l}\text { Environmental } \\
\text { Research and } \\
\text { Public Health }\end{array}$ & & & & & \\
\hline Fudan University & 148 & $\begin{array}{l}\text { Environment } \\
\text { International }\end{array}$ & 239 & $\begin{array}{c}\text { United States } \\
\text { Environmental } \\
\text { Protection Agency }\end{array}$ & 189 & $\begin{array}{l}\text { Environment } \\
\text { International }\end{array}$ & 222 \\
\hline $\begin{array}{l}\text { University of } \\
\text { Washington, } \\
\text { Seattle }\end{array}$ & 131 & $\begin{array}{l}\text { Environmental } \\
\text { Science and } \\
\text { Pollution Research }\end{array}$ & 189 & Fudan University & 154 & $\begin{array}{l}\text { Environmental Science } \\
\text { and Pollution Research }\end{array}$ & 203 \\
\hline $\begin{array}{l}\text { Utrecht } \\
\text { University }\end{array}$ & 115 & $\begin{array}{l}\text { Environmental } \\
\text { Health } \\
\text { Perspectives }\end{array}$ & 161 & $\begin{array}{c}\text { University of } \\
\text { Washington Seattle }\end{array}$ & 144 & $\begin{array}{l}\text { Environmental Health } \\
\text { Perspectives }\end{array}$ & 170 \\
\hline $\begin{array}{l}\text { Tsinghua } \\
\text { University }\end{array}$ & 114 & $\begin{array}{c}\text { Environmental } \\
\text { Science and } \\
\text { Technology }\end{array}$ & 158 & $\begin{array}{l}\text { University of } \\
\text { Washington }\end{array}$ & 144 & $\begin{array}{l}\text { Environmental Science } \\
\text { \& Technology }\end{array}$ & 146 \\
\hline $\begin{array}{c}\text { Swiss Tropical } \\
\text { and Public Health } \\
\text { Institute Swiss } \\
\text { TPH }\end{array}$ & 107 & PLOS ONE & 134 & University of London & 127 & PLOS ONE & 140 \\
\hline
\end{tabular}


Lee et al. I Research trends concering particulate matter and health impact

Table 1b. Top 10 Organizations and journals regarding research on $\mathrm{PM}_{2.5}$ and health impact (2014-2018).

\begin{tabular}{|c|c|c|c|c|c|c|c|}
\hline \multicolumn{4}{|c|}{ Scopus database } & \multicolumn{4}{|c|}{ Web of Science database } \\
\hline Organization & & Journal & & Organization & & Journal & \\
\hline $\begin{array}{c}\text { Chinese Academy of } \\
\text { Sciences }\end{array}$ & 179 & $\begin{array}{c}\text { Science of the } \\
\text { Total Environment }\end{array}$ & 173 & Harvard University & 254 & $\begin{array}{l}\text { Science of the Total } \\
\text { Environment }\end{array}$ & 205 \\
\hline $\begin{array}{l}\text { Harvard School of } \\
\text { Public Health }\end{array}$ & 166 & $\begin{array}{l}\text { Atmospheric } \\
\text { Environment }\end{array}$ & 156 & $\begin{array}{c}\text { Chinese Academy } \\
\text { of Sciences }\end{array}$ & 223 & $\begin{array}{l}\text { Atmospheric } \\
\text { Environment }\end{array}$ & 201 \\
\hline Peking University & 118 & $\begin{array}{l}\text { International } \\
\text { Journal of } \\
\text { Environmental } \\
\text { Research And } \\
\text { Public Health }\end{array}$ & 142 & $\begin{array}{c}\text { University of } \\
\text { California system }\end{array}$ & 209 & $\begin{array}{c}\text { International Journal of } \\
\text { Environmental } \\
\text { Research and Public } \\
\text { Health }\end{array}$ & 184 \\
\hline $\begin{array}{c}\text { Ministry of } \\
\text { Education China }\end{array}$ & 111 & $\begin{array}{l}\text { Environmental } \\
\text { Research }\end{array}$ & 141 & Peking University & 154 & $\begin{array}{l}\text { Environment } \\
\text { International }\end{array}$ & 179 \\
\hline Fudan University & 94 & $\begin{array}{l}\text { Environment } \\
\text { International }\end{array}$ & 139 & $\begin{array}{c}\text { Harvard T.H. Chan } \\
\text { School of Public } \\
\text { Health }\end{array}$ & 143 & $\begin{array}{l}\text { Environmental } \\
\text { Pollution }\end{array}$ & 179 \\
\hline $\begin{array}{l}\text { United States } \\
\text { Environmental }\end{array}$ & 86 & $\begin{array}{l}\text { Environmental } \\
\text { Pollution }\end{array}$ & 139 & $\begin{array}{l}\text { United States } \\
\text { Environmental }\end{array}$ & 118 & $\begin{array}{l}\text { Environmental } \\
\text { Research }\end{array}$ & 161 \\
\hline Protection Agency & & & & Protection Agency & & & \\
\hline $\begin{array}{c}\text { University of } \\
\text { Washington, Seattle }\end{array}$ & 83 & $\begin{array}{l}\text { Environmental } \\
\text { Health } \\
\text { Perspectives }\end{array}$ & 93 & $\begin{array}{c}\text { University of } \\
\text { Washington Seattle }\end{array}$ & 113 & $\begin{array}{c}\text { Environmental Health } \\
\text { Perspectives }\end{array}$ & 133 \\
\hline Tsinghua University & 81 & $\begin{array}{c}\text { Environmental } \\
\text { Science and } \\
\text { Pollution Research }\end{array}$ & 84 & $\begin{array}{l}\text { University of } \\
\text { Washington }\end{array}$ & 113 & $\begin{array}{l}\text { Environmental Science } \\
\text { and Pollution Research }\end{array}$ & 123 \\
\hline Emory University & 72 & $\begin{array}{l}\text { Environmental } \\
\text { Science And } \\
\text { Technology }\end{array}$ & 78 & Fudan University & 110 & $\begin{array}{l}\text { Environmental Science } \\
\quad \& \text { Technology }\end{array}$ & 110 \\
\hline $\begin{array}{l}\text { Harvard Medical } \\
\text { School }\end{array}$ & 67 & PLOS ONE & 63 & Tsinghua University & 102 & $\begin{array}{l}\text { Aerosol and Air } \\
\text { Quality Research }\end{array}$ & 94 \\
\hline
\end{tabular}

The 10 journals that published the most articles on particulate matter ( $\mathrm{PM}_{10}$ and $\left.\mathrm{PM}_{2.5}\right)$ and health impact between 2014 and 2018 are presented in Table 1a. More than 30\% (Scopus =2,280, 33.8\%; WoS =2,235, 34.4\%) of the articles on PM10 and health impact were published in the top 10 journals. As per Scopus data, Science of the Total Environment (impact factor $=5.589,2018)$ was the most preferred journal $(376,5.6 \%$ of all publications on PM10 and health impact), followed by Atmospheric Environment (impact factor $=4.012$, 2018) with 281 articles (4.2\%), Environmental Pollution (impact factor $=$ 5.714, 2018) with 249 articles (3.7\%), and Environmental Research (impact factor $=5.026,2018$ ) with 249 articles. In WoS, Science of the Total Environment was the most common journal (341,5.3\%), followed by Atmospheric Environment with 284 publications (4.4\%) and International Journal of Environmental Research and Public Health (impact factor $=2.468,2018$ ) with 249 publications $(3.8 \%)$.

More than 35\% (Scopus = 1,208, 36.1\%; WoS = 1,569, 38.0\%) of articles on PM2.5 and health impact were published in the top 10 journals (Table 1b). In both Scopus and WoS, Science of the Total Environment was the most preferred journal (Scopus $=173,5.2 \%$ of all publications on PM2.5 and health impact; WoS $=205,5.0 \%$ ), followed by Atmospheric Environment with $156(4.7 \%)$ and 201 articles (4.9\%), and International Journal of Environmental Research and Public Health with 142 $(4.2 \%)$ and 184 articles $(4.5 \%)$, respectively. 
Table 2. Keyword analysis of articles on PM10 and health impact (2000-2018).

\begin{tabular}{ccc} 
Keywords & Count & $\%$ \\
Mortality & 3,327 & 33.2 \\
Cardiovascular Disease & 1,865 & 18.6 \\
Environmental Exposure & 1,809 & 18.0 \\
Ozone & 1,789 & 17.8 \\
Asthma & 1,727 & 17.2 \\
Respiratory Tract Infection & 1,709 & 17.0 \\
Exhaust Gas & 1,535 & 15.3 \\
Nitrogen Dioxide & 1,463 & 14.6 \\
Polycyclic Aromatic Hydrocarbon & 1,274 & 12.7 \\
Indoor Air Pollution & 1,141 & 11.4 \\
Sulfur Dioxide & 1,095 & 10.9 \\
Smoke & 897 & 8.9 \\
Time Series Analysis & 876 & 8.7 \\
Chronic Exposure & 820 & 8.2 \\
Beijing & 722 & 7.2 \\
\hline
\end{tabular}

\section{Keyword analyses}

In order to identify directions and key themes in the research on particulate matter ( $\mathrm{PM}_{10}$ and $\left.\mathrm{PM}_{2.5}\right)$ and health impact, we analyzed the top 15 keywords used in publications published between 2010 and 2018 available in Scopus. In $\mathrm{PM}_{10}$-related articles, the most frequently used keyword was "mortality" (3,327, 33.2\% of all publications on $\mathrm{PM}_{10}$ and health impact) (Table 2 and Supplemental Figure 1). Disease-related terms such as "cardiovascular disease" (1,865, 18.6\%), "asthma" $(1,727,17.2 \%)$, and "respiratory tract infection" $(1,709,17.0 \%)$ were ranked in the top 15 . Air pollutant-related terms (such as "nitrogen dioxide", "polycyclic aromatic hydrocarbon", and "sulfur dioxide") were also included in the top 15.

In case of PM2.5-related articles, the most frequently used keywords in these articles were "ozone" $(895,18.7 \%$ of all publications on PM 2.5 and health impact), followed by "asthma" (883, 18.4\%) and "environmental exposure" (872, 18.2\%) (Table 3 and Supplemental Figure 2). The terms "respiratory tract infection" (827, 17.3\%), "chronic obstructive lung disease" $(419,8.7 \%)$, and "lung neoplasm" (354, 7.4\%) were ranked 4th, 11th, and 15th, respectively. Air pollutant-related terms (such as "nitrogen dioxide", "polycyclic aromatic hydrocarbon", "exhaust gas" and "black carbon") and "indoor air pollution" were also included in the top 15.

$\mathrm{PM}_{2.5}$ is more harmful to health than $\mathrm{PM}_{10}$ [3]. Thus, the keyword analysis was conducted to identify key research topics especially in the United States and China, as they appear to have been leading the global research on the health effects of $\mathrm{PM}_{2.5}$. Keywords used in $\mathrm{PM}_{2.5}$ and health-related publications from the United States and China were compared. "Mortality" (438, 23.0\%; 222, 16.7\%), "respiratory tract infection" (193, 10.1\%; 173, 13.0\%), and "indoor air pollution" (174, 9.1\%; 72, 5.4\%) were the main keywords in publications from both countries. "Cardiovascular disease" (327, 17.2\%), "asthma" (203, 10.7\%), "ozone" (286, 15.0\%), "nitrogen dioxide" (163, 8.6\%), and "black carbon" (148, 7.8\%) were the high-frequency keywords in publications from the United States but not China. "Polycyclic aromatic hydrocarbon" (111, 8.4\%), "heavy metal" (91, 6.9\%), "lung neoplasm" (91, 6.9\%), and "chronic obstructive lung disease" (67, 5.0\%) were highly frequent only in Chinese publications. 


\begin{tabular}{|c|c|c|c|c|c|c|c|c|c|}
\hline Rank & All countries & Count & $\%$ & USA & Count & $\%$ & China & Count & $\%$ \\
\hline 1 & Ozone & 895 & 18.7 & Mortality & 438 & 23.0 & China & 769 & 58.0 \\
\hline 2 & Asthma & 883 & 18.4 & $\begin{array}{c}\text { Environmental } \\
\text { Exposure }\end{array}$ & 435 & 22.8 & City & 308 & 23.2 \\
\hline 3 & $\begin{array}{l}\text { Environmental } \\
\text { Exposure }\end{array}$ & 872 & 18.2 & $\begin{array}{c}\text { Cardiovascular } \\
\text { Disease }\end{array}$ & 327 & 17.2 & Beijing & 241 & 18.2 \\
\hline 4 & $\begin{array}{l}\text { Respiratory Tract } \\
\text { Infection }\end{array}$ & 827 & 17.3 & Ozone & 286 & 15.0 & Mortality & 222 & 16.7 \\
\hline 5 & Nitrogen Dioxide & 644 & 13.4 & $\begin{array}{l}\text { Chronic } \\
\text { Exposure }\end{array}$ & 211 & 11.1 & $\begin{array}{l}\text { Respiratory Tract } \\
\text { Infection }\end{array}$ & 173 & 13.0 \\
\hline 6 & Indoor Air Pollution & 634 & 13.2 & Asthma & 203 & 10.7 & $\begin{array}{l}\text { Environmental } \\
\text { Exposure }\end{array}$ & 163 & 12.3 \\
\hline 7 & $\begin{array}{c}\text { Polycyclic Aromatic } \\
\text { Hydrocarbon }\end{array}$ & 588 & 12.3 & $\begin{array}{l}\text { Respiratory } \\
\text { Tract Infection }\end{array}$ & 193 & 10.1 & $\begin{array}{c}\text { Polycyclic Aromatic } \\
\text { Hydrocarbon }\end{array}$ & 111 & 8.4 \\
\hline 8 & Chronic Exposure & 531 & 11.1 & Exhaust Gas & 191 & 10.0 & $\begin{array}{c}\text { Time Series } \\
\text { Analysis }\end{array}$ & 93 & 7.0 \\
\hline \multirow[t]{2}{*}{9} & Exhaust Gas & 508 & 10.6 & $\begin{array}{l}\text { Indoor Air } \\
\text { Pollution }\end{array}$ & 174 & 9.1 & Heavy Metal & 91 & 6.9 \\
\hline & & & & & & & Lung Neoplasm & 91 & 6.9 \\
\hline 10 & Beijing & 507 & 10.6 & $\begin{array}{l}\text { Nitrogen } \\
\text { Dioxide }\end{array}$ & 163 & 8.6 & Haze & 88 & 6.6 \\
\hline 11 & $\begin{array}{c}\text { Chronic Obstructive } \\
\text { Lung Disease }\end{array}$ & 419 & 8.7 & Black Carbon & 148 & 7.8 & Exhaust Gas & 85 & 6.4 \\
\hline 12 & Smoke & 412 & 8.6 & $\begin{array}{l}\text { Premature } \\
\text { Mortality }\end{array}$ & 142 & 7.5 & Chronic Exposure & 75 & 5.7 \\
\hline 13 & Black Carbon & 399 & 8.3 & California & 135 & 7.1 & $\begin{array}{l}\text { Indoor Air } \\
\text { Pollution }\end{array}$ & 72 & 5.4 \\
\hline 14 & Hospital Admission & 366 & 7.6 & Smoke & 133 & 7.0 & $\begin{array}{l}\text { Air Pollution } \\
\text { Control }\end{array}$ & 71 & 5.4 \\
\hline 15 & Lung Neoplasm & 354 & 7.4 & Cooking & 112 & 5.9 & $\begin{array}{l}\text { Chronic Obstructive } \\
\text { Lung Disease }\end{array}$ & 67 & 5.0 \\
\hline
\end{tabular}

\section{Subject area}

We analyzed the subject areas (Figure 3) of publications on PM2.5 and health impact published between 2014 and 2018. According to the distribution of subject categories, environmental science $\left(2,046,61.1 \%\right.$ of all publications on $\mathrm{PM}_{2.5}$ and health impact) and medicine $(1,135,33.9 \%)$ were the most common as per Scopus. In case of WoS, environmental science $(2,489,60.3 \%)$ and public, environmental, and occupational health $(1,054,25.5 \%)$ were the most common categories. The respiratory system $(130,3.1 \%)$ and cardiac and cardiovascular systems $(76,1.8 \%)$ stood at the seventh and ninth spots, respectively. 
A

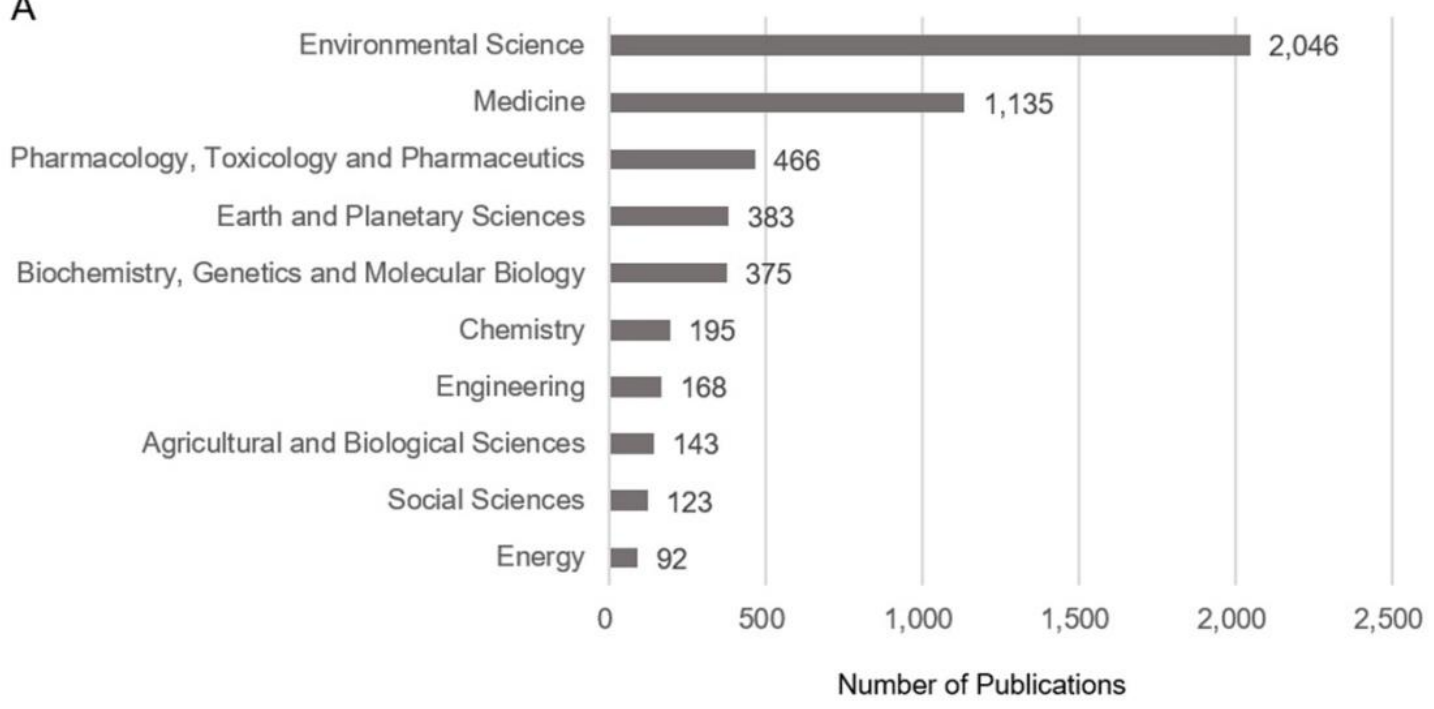

B

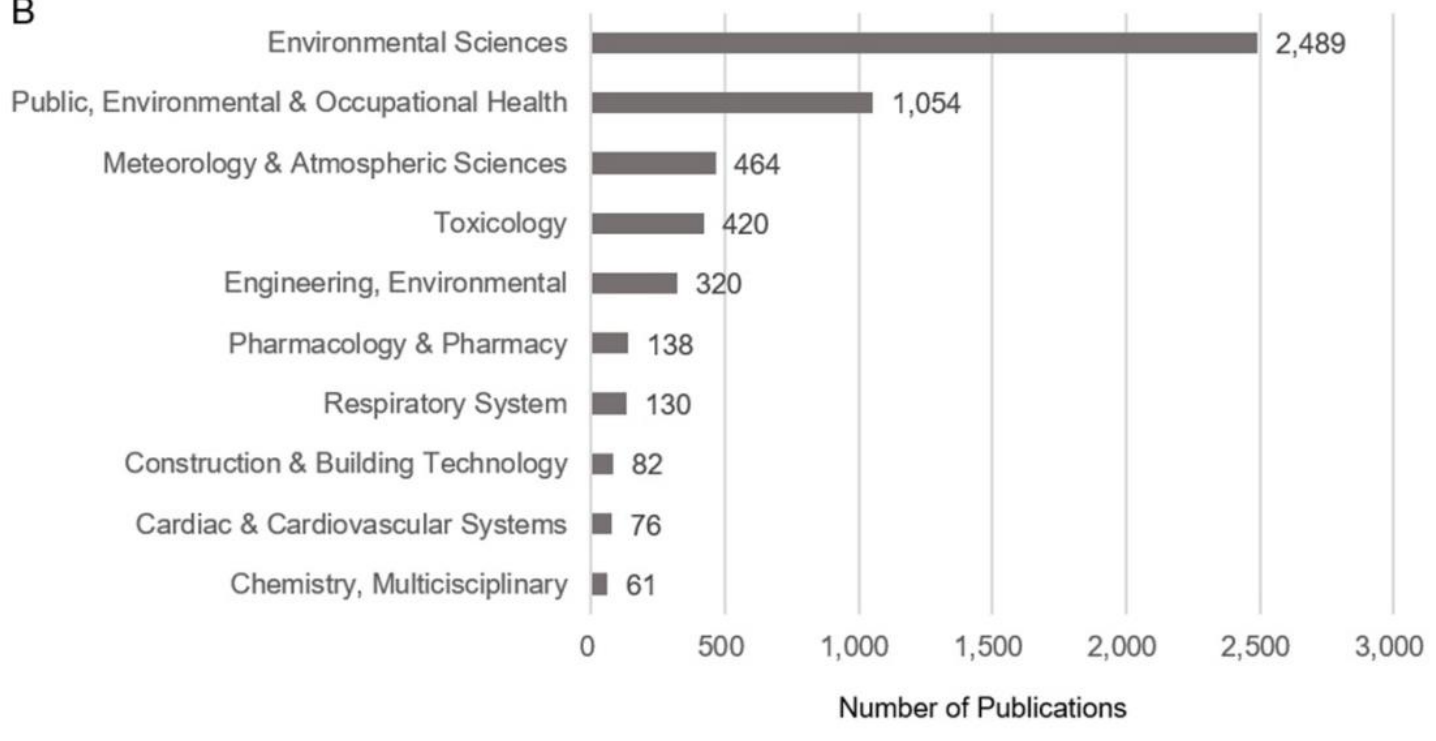

Figure 3. Top 10 subject categories of research on particulate matter and health impact. (A) Subject areas of publications on $\mathrm{PM}_{10}$ and health impact; (B) Subject areas of publications on $\mathrm{PM}_{2.5}$ and health impact.

\section{Publication trends regarding vulnerable population groups}

As mentioned previously, children, older adults, and pregnant women can be more vulnerable to the health impact of particulate matter than other populations. Thus, we examined how much research attention the health impact of $\mathrm{PM}_{2.5}$ in these groups has received over 10 years. Articles on children, older adults, and pregnant women were extracted from studies on PM2.5 and health impact published between 2009 and 2018 (Figure 4). In Scopus, the number of publications on children, older adults, and pregnant women were 732 (15.5\% of total publications on PM2.5 and health impact), 406 (8.6\%), and $196(4.2 \%)$ and increased 5.0, 5.1, and 7.2 times in 10 years, respectively. In WoS, the number of publications on children, older adults, and pregnant women were $721(12.6 \%), 263(4.6 \%)$, and $178(3.1 \%)$ and increased 4.1, 3.4, and 6.3 times in 10 years, respectively. Thus, the increase in publications on pregnant women over the past 10 years is greater than the growth in the literature on $\mathrm{PM}_{2.5}$ and health effects; publications on $\mathrm{PM}_{2.5}$ and health effects increased 3.5 and 4.6 times in Scopus and WoS data, respectively. 
A

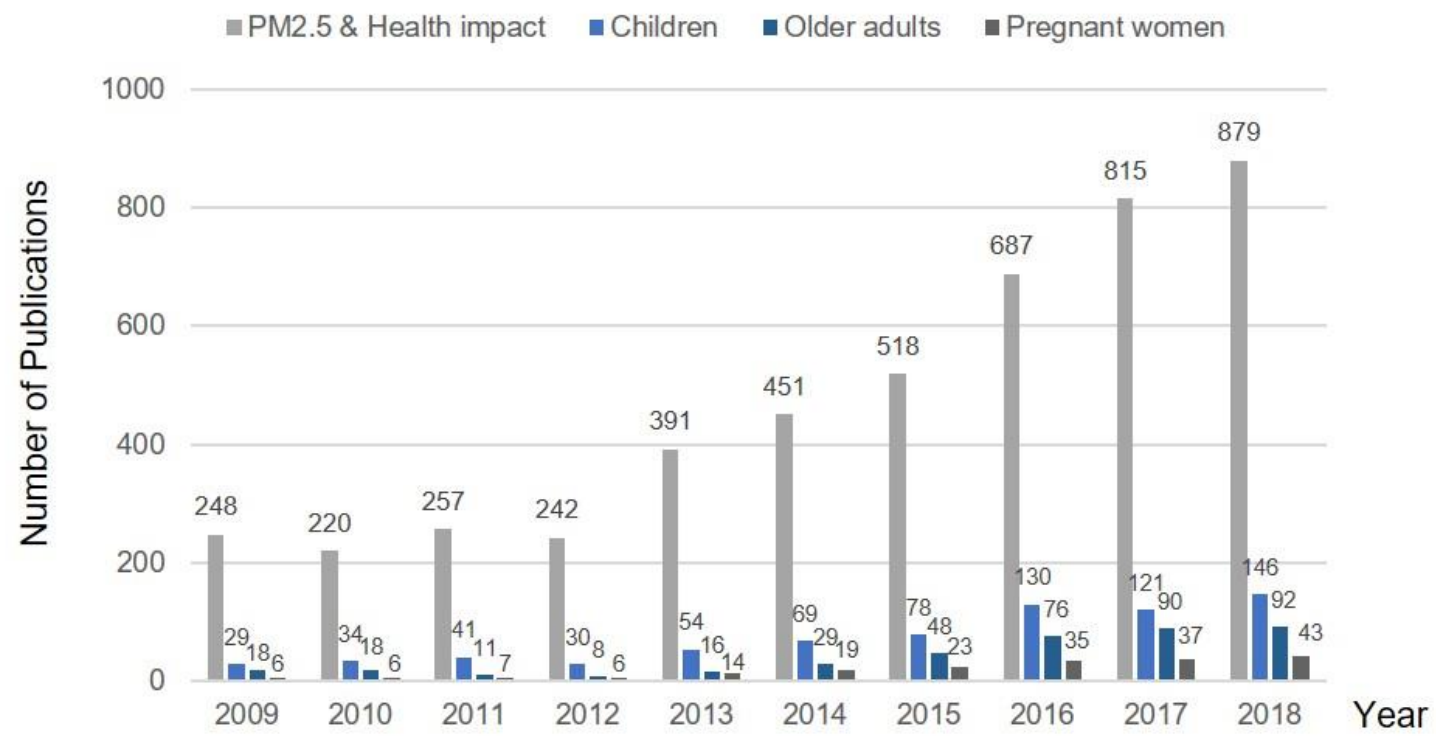

B

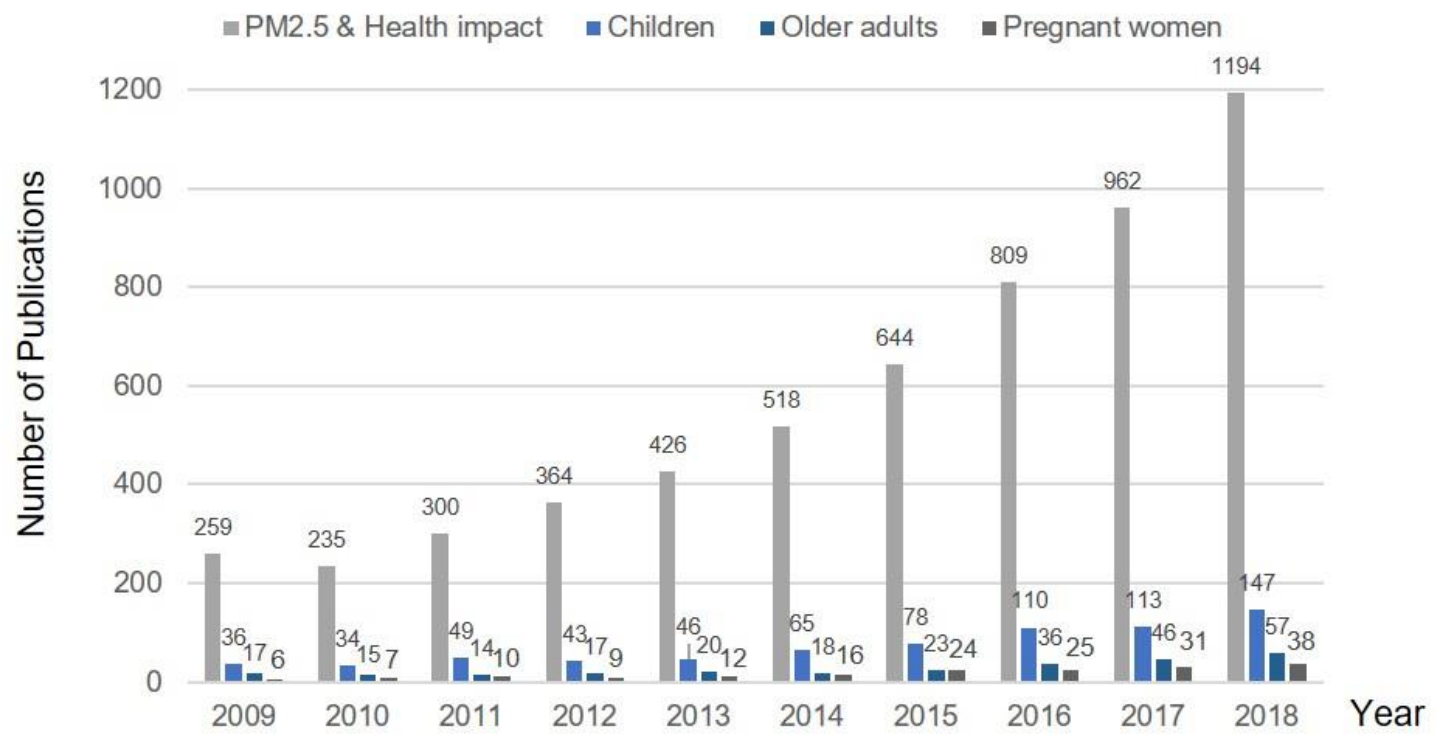

Figure 4. Trends of publications on $\mathrm{PM}_{2.5}$ and health impact in children, older adults, and pregnant women. (A)

Scopus data; (B) Web of Science data.

\section{Keyword analyses of publications on vulnerable population groups}

The most frequently used keywords in articles on children, older adults, and pregnant women, which were published between 2010 and 2018, were "asthma" (209, 29.7\% of children-related articles), "mortality" (139, 35.8\% of the articles on older adults), and "exposure" (169, 88.9\% of pregnant women -related articles), respectively (Table 4 and Supplemental Figure 3). "Asthma", "respiratory tract infection" (158, 22.5\%), "cardiovascular disease" (65, 9.2\%), and "respiratory tract disease" $(61,8.7 \%)$ were the main keywords in children-related publications. Air pollutant-related terms such as "nitrogen dioxide" (112, 15.9\%) and "polycyclic aromatic hydrocarbon" (54, 7.7\%) also ranked in the top 15. Six disease-associated terms including "cardiovascular diseases" (126, 32.5\%), "respiratory tract infection" (64, 16.5\%), "chronic obstructive lung disease" (43, 11.1\%), "stroke" (34, 8.8\%), "asthma" (31, 8.0\%), and "respiratory tract disease" (28, 7.2\%) were among the top 15 keywords in the publications on older adults. Fetal growth-related terms such as "birth weight" (40, $21.1 \%)$, "low birth weight infant" (30,15.8\%), and "low birth weight" (18, 9.5\%) were among the main keywords in publications on pregnant women. 
Table 4. Keyword analysis of articles on PM2.5 and health impact in children, older adults, and pregnant women (2000-2018).

\begin{tabular}{|c|c|c|c|c|c|c|c|c|c|}
\hline Rank & Child & count & $\%$ & Older adults & count & $\%$ & $\begin{array}{c}\text { Pregnant } \\
\text { women }\end{array}$ & count & $\%$ \\
\hline 1 & Asthma & 209 & 29.7 & Mortality & 139 & 35.8 & Exposure & 169 & 88.9 \\
\hline \multirow{2}{*}{2} & & & & Environmental & & & Maternal & & \\
\hline & Child Health & 202 & 28.7 & Exposure & 138 & 35.6 & Exposure & 91 & 47.9 \\
\hline \multirow{2}{*}{3} & Environmental & & & Cardiovascular & & & & & \\
\hline & Exposure & 178 & 25.3 & Disease & 126 & 32.5 & Mother & 82 & 43.2 \\
\hline \multirow{2}{*}{4} & Respiratory Tract & & & & & & Prenatal & & \\
\hline & Infection & 158 & 22.5 & Chronic Exposure & 78 & 20.1 & Exposure & 59 & 31.1 \\
\hline \multirow{3}{*}{5} & & & & & & & Pregnancy & & \\
\hline & Ozone & 118 & 16.8 & Nitrogen Dioxide & 65 & 16.8 & Outcome & 54 & 28.4 \\
\hline & & & & Ozone & 65 & 16.8 & & & \\
\hline \multirow{2}{*}{6} & & & & Respiratory Tract & & & & & \\
\hline & Nitrogen Dioxide & 112 & 15.9 & Infection & 64 & 16.5 & Cohort Study & 49 & 25.8 \\
\hline \multirow{3}{*}{7} & & & & & & & Environmental & & \\
\hline & Indoor Air Pollution & 110 & 15.6 & Hospitalization & 61 & 15.7 & Exposure & 41 & 21.6 \\
\hline & & & & Time Series Analysis & 61 & 15.7 & & & \\
\hline 8 & School & 75 & 10.7 & Hospital Admission & 58 & 14.9 & Birth Weight & 40 & 21.1 \\
\hline \multirow{2}{*}{9} & & & & Chronic Obstructive & & & Premature & & \\
\hline & School child & 69 & 9.8 & Lung Disease & 43 & 11.1 & Labor & 32 & 16.8 \\
\hline \multirow[t]{2}{*}{10} & $\begin{array}{l}\text { Cardiovascular } \\
\text { Disease }\end{array}$ & 65 & 9.2 & Crossover Procedure & 36 & 9.3 & $\begin{array}{l}\text { Birth Cohort } \\
\text { Low Birth }\end{array}$ & 30 & 15.8 \\
\hline & & & & & & & $\begin{array}{l}\text { Weight Infant } \\
\text { Nitrogen }\end{array}$ & 30 & 15.8 \\
\hline 11 & Exhaust Gas & 64 & 9.1 & Stroke & 34 & 8.8 & Dioxide & 28 & 14.7 \\
\hline 12 & Lung Function & 63 & 9.0 & Sulfur Dioxide & 32 & 8.2 & Child Health & 27 & 14.2 \\
\hline \multirow{5}{*}{13} & Time Series Analysis & 63 & 9.0 & & & & & & \\
\hline & Hospital Emergency & & & & & & & & \\
\hline & Service & 61 & 8.7 & Asthma & 31 & 8.0 & Land Use & 25 & 13.2 \\
\hline & Respiratory Tract & & & & & & Maternal & & \\
\hline & Disease & 61 & 8.7 & & & & Welfare & 25 & 13.2 \\
\hline 14 & Hospital Admission & 58 & 8.3 & $\begin{array}{c}\text { Respiratory Tract } \\
\text { Disease }\end{array}$ & 28 & 7.2 & Early Life & 19 & 10.0 \\
\hline \multirow{2}{*}{15} & Polycyclic Aromatic & & & & & & Low Birth & & \\
\hline & Hydrocarbon & 54 & 7.7 & Mortality Risk & 25 & 6.4 & Weight & 18 & 9.5 \\
\hline
\end{tabular}

\section{Discussion and conclusion}

In this study, we analyzed the trends in scientific publications on the health impact of $\mathrm{PM}_{10}$ and $\mathrm{PM}_{2.5}$ over 10 years (2009-2018). The number of studies on health impacts in both the PM10 and $\mathrm{PM}_{2.5}$ research fields increased rapidly over the period under consideration.

This increase appears to be spearheaded by researchers from the United States and China. China contributed approximately half of the number of studies published by researchers from the United States. According to the 2015 Global Burden of Disease study, China ranked highest with regard to the global disease burden attributable to ambient $\mathrm{PM}_{2.5}$ exposure [4]; PM2.5 caused 1.1 million (95\% UI 1.0 million-1.8 million) deaths in China, accounting for more than $26 \%$ of the 4.2 million (95\% UI 3.7 million-4.8 million) deaths worldwide. In the United States, the number of PM2.5 deaths was 88,400 (95\% UI 66,800-115,000), approximately one-twelfth of the deaths in China. It can, thus, be assumed that awareness of the seriousness of the health effects of particulate matter is higher in the United States than in China.

The top 10 organizations that contributed to articles on the health impact of $\mathrm{PM}_{10}$ and $\mathrm{PM}_{2.5}$ from 2014 to 2018 were mostly from the United States and China, demonstrating that world-class research institutions play an important role in improving national research performance. 
Lee et al. I Research trends concering particulate matter and health impact

Science of the Total Environment and Atmospheric Environment published the most articles (about 10\%) on health effects of $\mathrm{PM}_{10}$ and $\mathrm{PM}_{2.5}$ from 2014 to 2018 . The top 10 journals have contributed to more than $30 \%$ of the literature on health effects in both the $\mathrm{PM}_{10}$ and $\mathrm{PM}_{2.5}$ research fields and are expected to continue to lead the way with regard to the study of particulate matter and its health effects.

To identify the major topics in research on particulate matter and health effects, we performed a keyword analysis. Air pollutants such as "nitrogen dioxide", "polycyclic aromatic hydrocarbon", "sulfur dioxide", and "black carbon" were high-frequency keywords in global publications on particulate matter ( $\mathrm{PM}_{10}$ or $\left.\mathrm{PM}_{2.5}\right)$ and health effects. This finding indicates that the precursors to and components of particulate matter have been frequently studied in this field. Respiratory diseases seem to have been key topics in the field of research on the health impact of PM10 and PM2.5. While "mortality" was most often used in publications related to PM10 and health effects, it was not included in the top 15 in $\mathrm{PM}_{2.5}$ and health effects. Since $\mathrm{PM}_{2.5}$ is smaller than $\mathrm{PM}_{10}$, it is able to reach small airways and pulmonary alveoli [19] and move to other organs through the circulatory system [2], thereby posing a greater threat [3]. In global publications, the terms "asthma", "respiratory tract infection", "chronic obstructive lung disease", and "lung neoplasm" were frequently used as keywords in the literature on PM2.5 and health impact. "Cardiovascular disease" was the high-frequency keyword in publications from the United States. Many researchers have reported that ambient PM$_{2.5}$ is an important risk factor for cardiovascular disease $[4,20]$ and respiratory diseases including lung cancer $[4,21]$, chronic obstructive pulmonary disease $[4,22]$, and asthma [23,24]. In addition, $\mathrm{PM}_{2.5}$ can play a role in depressive symptoms [25,26], stroke [20,26-29], dementia [29], Alzheimer's disease [29], diabetes mellitus [30], and ocular diseases [31,32], but there is a lack of research in this regard. To better understand the health effects of $\mathrm{PM}_{2.5}$, research on various diseases should be actively conducted. We also identified that articles published in the United States and China had different keyword patterns; for example, "cardiovascular disease" and "asthma" were frequently used only in American publications, while "lung neoplasm" and "chronic obstructive lung disease" were highly frequent in only Chinese publications.

The number of publications related to the susceptible groups of children, older adults, and pregnant women in the field of $\mathrm{PM}_{2.5}$ and health effects has increased significantly over 10 years but remains small, indicating the possibility of expansion of such research. As per keyword analysis, the major research topics for these three populations differed. In studies on children, respiratory diseases such as asthma were a popular topic. Air pollutants such as nitrogen dioxide and polycyclic aromatic hydrocarbon, of which diesel engines are the main source, also seem to have attracted scholarly attention. A previous study has reported that $\mathrm{PM}_{2.5}$ and nitrogen dioxide are involved in the exacerbation of childhood asthma [8]. In studies on older adults, mortality was the most popular research topic, and the names of diseases ("cardiovascular diseases", "respiratory tract infection", "chronic obstructive lung disease", "stroke", "asthma", and "respiratory tract disease") were highly frequent. Studies on pregnant women seemed to focus on fetal health rather than the health of the women.

Despite the fact that it revealed some important trends, our bibliometric approach had certain limitations. First, all scientific publications in the fields of particulate matter (both $\mathrm{PM}_{10}$ and $\mathrm{PM}_{2.5}$ ) and health impact were not necessarily included. Second, the weight of importance of each article was not reflected. Third, bibliometric databases might contain erroneous data [18]. Fourth, the literature extracted may differ slightly depending on the time of search. Nevertheless, the bibliometric method is an objective and comprehensive way to analyze publication trends [33]. Moreover, we used two bibliometric tools, thereby increasing the credibility of the data.

We have demonstrated that, worldwide, there has been an impressive increase in the number of scientific publications in the fields of particulate matter and health impact over 10 years. This increase appears to be led by worldclass research institutes in the United States and China. A large amount of work on particulate matter and health effects has focused on respiratory and cardiovascular diseases. The precursors to and components of particulate matter (such as nitrogen dioxide, polycyclic aromatic hydrocarbon, sulfur dioxide, and black carbon) were also core research topics. Studies on children, older adults, and pregnant women in the field of $\mathrm{PM}_{2.5}$ and health impact are expected to expand greatly in the future.

\section{Acknowledgement}

This research was supported by funds (2019-NI-102-00, 2019-NI-098-00) from the Korea Centers for Disease Control and Prevention.

\section{Conflict of interest}

The authors have no conflicts of interest associated with the material presented in this paper.

\section{CRediT author statement}

JEL: Conceptualization, Methodology, Writing - Original, Writing - Reviewing and Editing, Visualization. HJL: Writing Reviewing and Editing, Supervision, Project administration, Funding acquisition. YYK: Supervision, Project administration, Funding acquisition. 


\section{ORCID}

Jae-Eun Lee: 0000-0001-5287-7419

Hyun Joung Lim: 0000-0002-1646-0787

Young-Youl Kim: 0000-0003-4143-6372

\section{Supplementary Material}

Add short descriptions of supplementary material. This material is available online at www.eaht.org.

\section{References}

[1] De Donno A, De Giorgi M, Bagordo F, Grassi T, Idolo A, Serio F, et al. Health risk associated with exposure to PM10 and benzene in three Italian towns. Int J Environ Res Public Health 2018;15(8):1672.

[2] Kim KH, Kabir E, Kabir S. A review on the human health impact of airborne particulate matter. Environ Int 2015;74:136-143.

[3] World Health Organization (WHO). Health effects of particulate matter. Policy implications for countries in eastern Europe, Caucasus and central Asia. World Health Organization Regional Office for Europe; 2013.

[4] Cohen AJ, Brauer M, Burnett R, Anderson HR, Frostad J, Estep K, et al. Estimates and 25-year trends of the global burden of disease attributable to ambient air pollution: an analysis of data from the Global Burden of Diseases Study 2015. Lancet 2017;389(10082):1907-1918.

[5] Andersen ZJ, Wahlin P, Raaschou-Nielsen O, Ketzel M, Scheike T, Loft S. Size distribution and total number concentration of ultrafine and accumulation mode particles and hospital admissions in children and the elderly in Copenhagen, Denmark. Occup Environ Med 2008;65(7):458-466.

[6] Kalkbrenner AE, Windham GC, Serre ML, Akita Y, Wang X, Hoffman K, et al. Particulate matter exposure, prenatal and postnatal windows of susceptibility, and autism spectrum disorders. Epidemiology 2015;26(1):3042.

[7] Askariyeh MH, Vallamsundar S, Zietsman J, Ramani T. Assessment of traffic-related air pollution: case study of pregnant women in south Texas. Int J Environ Res Public Health 2019;16(13):2433.

[8] Kuo CY, Chan CK, Wu CY, Phan DV, Chan CL. The short-term effects of ambient air pollutants on childhood asthma hospitalization in Taiwan: a national study. Int J Environ Res Public Health 2019;16(2):203.

[9] Samoli E, Nastos PT, Paliatsos AG, Katsouyanni K, Priftis KN. Acute effects of air pollution on pediatric asthma exacerbation: evidence of association and effect modification. Environ Res 2011;111(3):418-424.

[10] Gehring U, Wijga AH, Brauer M, Fischer P, de Jongste JC, Kerkhof M, et al. Traffic-related air pollution and the development of asthma and allergies during the first 8 years of life. Am J Respir Crit Care Med 2010;181(6):596603.

[11] Bowatte G, Lodge C, Lowe AJ, Erbas B, Perret J, Abramson MJ, et al. The influence of childhood traffic-related air pollution exposure on asthma, allergy and sensitization: a systematic review and a meta-analysis of birth cohort studies. Allergy 2015;70(3):245-256.

[12] Li T, Zhang Y, Wang J, Xu D, Yin Z, Chen H, et al. All-cause mortality risk associated with long-term exposure to ambient PM2.5 in China: a cohort study. Lancet Public Health 2018;3(10):e470-e477.

[13] Jung EJ, Na W, Lee KE, Jang JY. Elderly mortality and exposure to fine particulate matter and ozone. J Korean Med Sci 2019;34(48):e311.

[14] Liang Z, Yang Y, Qian Z, Ruan Z, Chang J, Vaughn MG et al. Ambient PM2.5 and birth outcomes: estimating the association and attributable risk using a birth cohort study in nine Chinese cities. Environ Int 2019;126:329-335.

[15] Hsu HH, Chiu YH, Coull BA, Kloog I, Schwartz J, Lee A, et al. Prenatal particulate air pollution and asthma onset in urban children. Identifying sensitive windows and sex differences. Am J Respir Crit Care Med 2015;192(9):10521059. 
[16] Qiu-Ju Lyu, Qiang-Hong Pu, Jin Zhang. Bibliometric analysis of scientific publications in endocrinology and metabolism from China, Japan, and South Korea. Scientometrics 2017;110(1):105-112.

[17] Yang S, Sui J, Liu T, Wu W, Xu S, Yin L, et al. Trends on PM2.5 research, 1997-2016: a bibliometric study. Environ Sci Pollut Res Int 2018;25(13):12284-12298.

[18] Dhital S, Rupakheti D. Bibliometric analysis of global research on air pollution and human health: 1998-2017. Environ Sci Pollut Res Int 2019;26(13):13103-13114.

[19] Kim SH, Yang HJ, Jang AS, Kim SH, Song WJ, Kim TB, et al. Effects of particulate matter in ambient air on the development and control of asthma. Allergy Asthma Respir Dis 2015;3(5):313-319.

[20] Hayes RB, Lim C, Zhang Y, Cromar K, Shao Y, Reynolds HR, et al. PM2.5 air pollution and cause-specific cardiovascular disease mortality. Int J Epidemiol 2020;49(1):25-35.

[21] Yang WS, Zhao H, Wang X, Deng Q, Fan WY, Wang L. An evidence-based assessment for the association between long-term exposure to outdoor air pollution and the risk of lung cancer. Eur J Cancer Prev 2016;25(3):163-172.

[22] Sarkar C, Zhang B, Ni M, Kumari S, Bauermeister S, Gallacher J, et al. Environmental correlates of chronic obstructive pulmonary disease in 96779 participants from the UK Biobank: a cross-sectional, observational study. Lancet Planet Health 2019;3(11):e478-e490.

[23] Silverman RA, Ito K. Age-related association of fine particles and ozone with severe acute asthma in New York City. J Allergy Clin Immunol 2010;125(2):367-373.

[24] Ko FW, Tam W, Wong TW, Lai CK, Wong GW, Leung TF, et al. Effects of air pollution on asthma hospitalization rates in different age groups in Hong Kong. Clin Exp Allergy 2007;37(9):1312-1319.

[25] Buoli M, Grassi S, Caldiroli A, Carnevali GS, Mucci F, Iodice S, et al. Is there a link between air pollution and mental disorders? Environ Int 2018;118:154-168.

[26] Niedzwiecki MM, Rosa MJ, Solano-Gonzalez M, Kloog I, Just AC, Martinez-Medina S, et al. Particulate air pollution exposure during pregnancy and postpartum depression symptoms in women in Mexico City. Environ Int 2020;134:105325.

[27] Huang K, Liang F, Yang X, Liu F, Li J, Xiao Q, et al. Long term exposure to ambient fine particulate matter and incidence of stroke: prospective cohort study from the China-PAR project. BMJ 2019;367:16720.

[28] Yuan S, Wang J, Jiang Q, He Z, Huang Y, Li Z, et al. Long-term exposure to PM2.5 and stroke: a systematic review and meta-analysis of cohort studies. Environ Res 2019;177:108587.

[29] Fu P, Guo X, Cheung FMH, Yung KKL. The association between PM2.5 exposure and neurological disorders: a systematic review and meta-analysis. Sci Total Environ 2019;655:1240-1248.

[30] He D, Wu S, Zhao H, Qiu H, Fu Y, Li X, et al. Association between particulate matter 2.5 and diabetes mellitus: a meta-analysis of cohort studies. J Diabetes Investig 2017;8(5):687-696.

[31] Chua SYL, Khawaja AP, Morgan J, Strouthidis N, Reisman C, Dick AD, et al. The relationship between ambient atmospheric fine particulate matter (PM2.5) and glaucoma in a large community cohort. Invest Ophthalmol Vis Sci 2019;60(14):4915-4923.

[32] Chen R, Yang J, Zhang C, Li B, Bergmann S, Zeng F, et al. Global associations of air pollution and conjunctivitis diseases: a systematic review and meta-analysis. Int J Environ Res Public Health 2019;16(19):3652.

[33] Gao Y, Wang Y, Zhai X, He Y, Chen R, Zhou J, et al. Publication trends of research on diabetes mellitus and T cells (1997-2016): a 20-year bibliometric study. PLoS One 2017;12(9):e0184869. 